Uniwersytet w Białymstoku

Wydział Filologiczny

Instytut Filologii Wschodniosłowiańskiej

tel.: +48857457450

e-mail: e_bogdanowicz@o2.pl

\title{
Metafory z nazwami własnymi w strukturze jako wykładnik wartościowania (na materiale polskiej i rosyjskiej publicystyki prasowej)
}

Słowa kluczowe: językoznawstwo, aksjologia, metafora, nazwa własna, konotacja, wartościowanie, wartość

Każdy człowiek, stykając się wprost albo też myślowo z poszczególnymi elementami rzeczywistości, dokonuje ich wartościowania (oceny), czyli uznaje pewne rzeczy za dobre, złe lub znajdujące się w jakimś punkcie skali między dobrym a złym. Odwołuje się przy tym do różnych wartości, realizowanych mniej lub bardziej świadomie w ramach określonej struktury społecznej i danego typu kultury [Gajda 1997, 16].

Istoty wartości i wartościowania nie da się określić jednoznacznie, stąd wiele propozycji ich definiowania w literaturze aksjologicznej [zob. m.in. Kamiński 1986, Puzynina 1992, Stróżewski 1992, Gajda 1997, Krzeszowski 1999]. W tym tekście przyjmuje rozumienie wartości i wartościowania zaproponowane przez J. Puzyninę, która za wartość uznaje „to, co dobre” ${ }^{\text {, }}$ cenne, godne pożądania i naśladowania, wartościowanie zaś pojmuje jako „czynność psychiczną człowieka polegającą na stwierdzeniu, jakie i w jakim stopniu wartości pozytywne lub negatywne właściwe są - zdaniem osoby wartościującej - danym cechom, zachowaniom, a pośrednio przedmiotom"

1 Opozycją do wartości jest antywartość, tj. to, co bywa uznawane za złe [Puzynina $1997,275]$. 
[Puzynina 1992, 83]. Wartościowanie jest zatem intelektualnym procesem uznawania czegoś za dobre bądź w jakiejś mierze złe.

Przypisywanie rzeczom wartości - dodatnich lub ujemnych - trwa przez całe życie człowieka. Z upływem lat ulegajac one naturalnym modyfikacjom, gdyż w wieku dojrzałym ludzie doceniają inne rzeczy, niż w dzieciństwie. Pewne wartości wpajają też środowiska (dom rodzinny czy szkoła), w jakich człowiek funkcjonuje na różnych etapach swego życia. W ten sposób tworzą się hierarchie wartości, które, zdaniem J. Bartmińskiego, sterują „konstruowaniem wizji rzeczywistości przez subiekt doświadczający [...] i konceptualizujący, tj. przez wspólnotę nosicieli języka lub twórczą jednostkę, a w kolejności stanowią czynnik integrujący elementy obrazu świata utrwalonego w tradycji i mającej obieg społeczny" [Bartmiński 2003, 63]. A to oznacza, że systemy wartości i modele wartościowania, obowiązujące w danej wspólnocie kulturowo-komunikatywnej, znajdują odwzorowanie i w języku, który jest nie tylko niezbędny do wszelkiego głębszego kontaktowania się ludzi między sobą, ale jest też wartością samą w sobie jako najważniejszy składnik ludzkiej kultury. Na języku opiera się egzystencja ludzi jako wspólnoty społecznej z wielowiekowym doświadczeniem. „Język, kumulując je w sobie (te wartości i doświadczenia - E. B.), daje strukturę postrzegania rzeczywistości, myślenia o niej i jej oceniania" [Kurczab 2012, 9-10].

Przekaz językowy, zarówno na poziomie systemu, jak i tekstu, dysponuje szerokim zestawem środków do dokonywania ocen ${ }^{2}$. Najbardziej wyrazistym i bogatym wykładnikiem wartościowania w obrębie systemu językowego są słowa. Niektóre leksemy mają charakter wyłącznie wartościujący, tj. w sensie semantycznym funkcjonują na zasadzie kontrastowania globalnego dobry/zły [Puzynina 1992, 118], np. pozytywny, negatywny, dodatni, ujemny, niezty, marny, jednak jest ich niewiele. Zdecydowanie większą grupę stanowią wyrazy, które w eksplikacjach definicyjnych obok oceniających zawierają cechy opisowe, tj. w odniesieniu do procesu wartościowania są pozbawione nacechowania oceniającego, np. złodziej, zdolny, donosicielstwo, opiekun.

Elementy wartościujące w obrazie znaczeniowym leksemu mogą być cechami drugorzędnymi, pozadefinicyjnymi, silnie kojarzonymi z obiektami, mniej lub bardziej ustabilizowanymi konotacjami, asocjacjami, tzn. sądami, opiniami na temat desygnatu danej nazwy - powszechnymi lub podzielanymi przez grupę społeczną, a nawet indywidualnymi. Odwołują się one

2 Językowe środki wyrażania wartości zostały stosunkowo dobrze rozpoznane [por. Puzynina 1992, 111-130, Laskowska 1992, Ożóg 2001]. 
do wiedzy, tradycji i kultury mówiących o tych obiektach, ale nie służą do ich identyfikacji. Związane są z użyciem testowym jednostki leksykalnej i stanowią swoiste dopełnienie oraz wzbogacenie znaczenia podstawowego. Jako przykłady słów wartościujących konotacyjnie można wskazać wyrazy krzyż lub kościót, które przez ludzi wierzących (chrześcijan) odbierane są pozytywnie.

W wartościowaniu otaczającej rzeczywistości, opartym na treściach konotacyjnych, uczestniczą nazwy własne, a miejscem, gdzie można wyodrębnić związane z nimi konotacje, jest odonimiczna płaszczyzna funkcjonowania nazw własnych, skupiająca różnorodne aspekty wtórnego wykorzystania onimów, tj. przypadki występowania ich w roli innej niż identyfikacja obiektów indywidualnych. Przesunięcie nazw własnych do obszaru użyć pozasystemowych, wtórnych przebiega w warunkach tzw. deonimizacji, czyli utraty lub przynajmniej tekstowego osłabienia związku denotacyjnego, uchylenia/zniesienia sztywnej desygnacji między nazwą a obiektem [Rutkowski 2007, 29]. „Niecodzienny”, „niezwykły”, nietypowy charakter użyć nazw własnych wyraża się też możliwością pełnienia funkcji predykatywnych - orzekania o cechach desygnatów [ibidem, 28], co w rezultacie prowadzi do „nasemantyzowania” propriów, czyli do powstania konotacji nazewniczych.

Jednym z przejawów nietypowego, wtórnego zastosowania nazw własnych, w których stają się nośnikami konotacji, są metaforyczne użycia propriów, oparte na znanym od czasów Arystotelesa, uniwersalnym mechanizmie komunikacyjnym, tzw. przenośni (metaforze), polegającej na odchyleniu od zwykłego, dosłownego użycia wyrazu - w tym przypadku na zastąpieniu nazwy jednego zjawiska inną dzięki istnieniu relacji podobieństwa między oznaczanymi przez nie desygnatami [Encyklopedia językoznawstwa ogólnego 2003, 361-363]. To klasyczne rozumienie metafory ${ }^{3}$ dotyczy wyrazów pospolitych, gdyż za punkt odniesienia uznaje cechy charakterystyczne porównywanych obiektów, będące składowymi przyporządkowanych im znaczeń leksykalnych ${ }^{4}$. Metafory z propriami w strukturze, czyli z jednostkami

3 O tym i wielu innych stanowiskach badawczych dotyczących metafory w: Dobrzyńska [1984: 11-31].

4 Znaczenie leksykalne wyrazu w ujęciu semantyki leksykalnej to stały zespół cech koniecznych i wystarczających do odróżnienia tego znaczenia od każdego innego, cech, które są obecne we wszystkich użyciach danej jednostki leksykalnej i pozwalają w sposób jednoznaczny i najbardziej ekonomiczny odgraniczyć dany wyraz - wraz z oznaczanymi przez niego obiektami otaczającego świata, uznawanymi za klasę - od innych w obrębie określonego kodu językowego [Tokarski 1984, 12-13, Apresjan 2000, 77]. Ten typ znaczenia zaliczany jest do atrybutów kategorialnych wyrazów pospolitych. 
wyrazowymi, zgodnie z powszechną opinią językoznawców, usytuowanymi poza płaszczyzną semantyki, co w konsekwencji oznacza brak znaczenia leksykalnego, odwołują się do innych treści znaczeniowych - konotacji nazewniczych, czyli rozmaitych, łączonych z nazwami własnymi, wyobrażeń o pierwotnych denotatach nazw, będących komponentem semantyki kulturowej obowiązującej w danej społeczności.

Na przykład, z formułą identyfikacyjną James Bond, określającą głównego bohatera powieści I. Fleminga oraz serii słynnych filmów przedstawiających awanturnicze przygody brytyjskiego agenta 007, związana jest wieloskładnikowa pozajęzykowa wiedza mówiących o obiekcie nazwy (tu: Bondzie), opierająca się na obiegowych, powszechnych sądach na jego temat: Bond to 1. 'as wywiadu', 2. 'inteligentny szpieg', 3. 'lojalny agent rządowy do specjalnych, tajnych misji', 4. 'agent z licencją na zabijanie', 5. 'supermen', 6. 'sprawny fizycznie mężczyzna', 7. 'odważny człowiek o ponadprzeciętnej sile moralnej', 8. 'osoba konsekwentnie zmierzająca do wykonania powierzonych jej zadań', 9. 'człowiek dokonujący niezwykłych czynów', 10. 'uwodziciel', 11. 'kobieciarz', 12. 'angielski dżentelmen o nienagannych manierach', 13. 'czarujący, przystojny, elegancki mężczyzna', 14. 'miłośnik dobrych samochodów, technologicznych gadżetów' itd. Każda z tych opinii o denotacie wskazywanym przez onim Bond potencjalnie mogłaby się przekształcić w jednostkową konotację i w dalszej kolejności - motywować konkretną metaforę nazewniczą.

Z powyższego wynika, że znaczeniowe umotywowanie dowolnej konotacji onimicznej związane jest z pozajęzykową wiedzą o obiekcie - prymarnym denotacie nazwy. Wiedza ta skupia wszystkie bez wyjątku cechy wyznaczanego desygnatu indywidualnego, znane człowiekowi, który danej nazwy używa. Tkwi ona w świadomości użytkowników jednostek proprialnych, należących do określonej wspólnoty kulturowo-językowej, w stanie gotowym do natychmiastowej aktualizacji.

Dużą skłonność do wytwarzania treści konotacyjnych wykazują onimy używane powszechnie typu Hitler, Napoleon, Waterloo, oznaczające denotaty z wyrazistą, przyciągającą uwagę wiedzą o nich, znane całej społeczności kulturowo-językowej lub znacznej jej części (np. imiona postaci mitologicznych, nazwiska bohaterów literackich, autentycznych postaci historycznych lub współczesnych: pisarzy, uczonych, polityków, artystów itp., nazwy geograficzne - państw, miast, rzek, mórz itd.). Możliwość taka nie przysługuje propriom, wskazującym obiekty „zwyczajne” (osoby, miejsca), które niczym specjalnym się nie wyróżniają i tym samym nie budzą zainteresowania. Co więcej, są właściwie anonimowe wśród większości członków danej wspólnoty komunikatywnej. 
Konotacja nazewnicza jako nośnik metaforyczny często przekazuje jakiś rodzaj wartościowania i w rezultacie wyrażenie przenośne z onimem, z którym jest powiązana, nie tylko odsłania pewne oblicze rzeczy lub zjawiska, ale też ukazuje swój przedmiot odniesienia w pewnej perspektywie aksjologicznej, narzucając tym samym odbiorcom metafor określoną postawę wartościującą.

Dla ukazania wartościującej funkcji przenośni sięgniemy do polskich i rosyjskich prasowych tekstów publicystycznych. Polskie metaforyczne ilustracje tekstowe z udziałem nazw własnych pochodzac z tygodników „Newsweek”, „Wprost”, „Polityka”, „wSieci”, rosyjskojęzyczne zaś wyekscerpowano z Narodowego Korpusu Języka Rosyjskiego (Национальный корпус русского языка), dostępnego na stronie internetowej ruscorpora.ru.

Zwroty metaforyczne zawierające nazwy własne nie są z reguły - jak wcześniej sygnalizowałam - neutralne aksjologicznie. Z tego również powodu stanowią wygodny środek perswazji w wypowiedziach prasowych, przy czym oceny przekazywane są tu za pośrednictwem odonimicznych treści konotacyjnych. Przykładowo, w określeniach przenośnych polski Hitler ( „Wprost” 2005, 47) - [o pewnym mieszkańcu Sokółki, który wzywał w swoich nazistowskich przemówieniach do obalenia władz w Polsce i zaprowadzenia ładu na wzór III Rzeszy], a także маленький Гитлер, Гитлер без вермахта, современный (Адольф) Гитлер - [wyrażenia z antroponimem Гитлер odnoszą się do byłego prezydenta Gruzji Micheila Saakaszwili, krytykowanego przez przeciwników politycznych za dyktatorskie zapędy w rządzeniu państwem, rozbudowywanie armii i państwowego aparatu przemocy] nazwa własna Hitler//Гumлep z konotacjami 'nazista', 'silny przywódca o skłonnościach dyktatorskich' narzuca zdecydowanie negatywne wartościowanie przedstawionej w metaforach rzeczywistości.

Pejoratywne oceny kryją w sobie też inne wypowiedzi przenośne z jednostkami proprialnymi w strukturze. Urbanistycznym Waterloo („Polityka" 2013, 10) nazwano, na przykład, położoną niemal w samym centrum Gdańska Wyspę Spichrzów, która powinna być dla deweloperów prawdziwym skarbem. Jednak tak nie jest, ponieważ od II wojny światowej miejsce to straszy ruinami, chwastami i górą śmieci, czyli zarządcy miasta ponieśli totalną klęskę (jak wojska francuskie pod wodzą Napoleona w starciu z armią koalicyjną w 1815 roku pod Waterloo), skazując Wyspę Spichrzów na powolne niszczenie. Za nowe wcielenie doktora Mengele („Newsweek" 2011, 47) uznano Waltera Freemana, amerykańskiego lekarza, który w latach czterdziestych i pięćdziesiątych ubiegłego stulecia stosował zabieg lobotomii w leczeniu chorób psychicznych, zamieniając tysiące ludzi w warzywa. W wymienionej metaforze został on porównany do Josefa Men- 
gele, niemieckiego lekarza i hitlerowskiego oficera, znanego ze zbrodniczej działalności w obozie koncentracyjnym Auschwitz-Birkenau podczas II wojny światowej, tzn. przeprowadzania pseudomedycznych eksperymentów na więźniach. Określenie этакий черногорский Обломов zawiera negatywną ocenę gry piłkarza z Czarnogóry Marka Bašy w moskiewskim klubie „Lokomotiw". Sportowiec ten na boisku nie przejawiał żadnej aktywności, często zastygał w nieruchomej pozie i rozglądał się wokół sennym, obojętnym wzrokiem, niczym Ilja Obłomow z rosyjskiej powieści Iwana Gonczarowa, człowiek całkowicie pozbawiony inicjatywy, bierny, pogrążony w bezwolnej apatii i sennej bezczynności. Konotacja wartościująca negatywnie 'zbrodniarz, morderca' wykorzystana została w roli tematu pomocniczego metafory żydowski Stalin w tekście o Herodzie Wielkim, namiestniku Galilei, królu Judei z łaski Rzymu w latach 37-34 p.n.e., który pod koniec życia był ogarnięty manią prześladowczą i dopuścił się wielu mordów, tropiąc rzeczywiste lub domniemane spiski, mogące pozbawić go władzy: Herod Wielki [...] jeden z największych potworów wszechczasów. Można go nazwać żydowskim Stalinem. W wykańczaniu przeciwników, sojuszników czy najbliższych krewnych nie miat sobie równych. Naprawdę lubit mordować („Newsweek” 2014, 16). Wyrażenie сербская Голгофа opisuje skutki krwawej wojny domowej w Kosowie pod koniec lat dziewięćdziesiątych XX wieku. Konflikt ten pochłonął tysiące ofiar, zarówno po stronie Albańczyków, jak i Serbów, był prawdziwą Golgotą tych narodów, czyli miejscem cierpienia, bólu i męczeństwa. Do przebiegu kosowskiej wojny odwołuje się też określenie drugie Kosowo ( „Newsweek” 2010, 26), które w wyrazisty sposób ilustruje wydarzenia na południu Kirgistanu. Zdaniem nadawcy komunikatu prasowego Rosja powinna posłać tam niezwłocznie wojsko, inaczej dojdzie do rzezi na niespotykaną skalę. $\mathrm{W}$ artykule prezentującym reakcje różnych ludzi - przeważnie szok i przerażenie - po serii ataków terrorystycznych, przeprowadzonych za pomocą porwanych samolotów pasażerskich 11 września 2001 roku na terytorium Stanów Zjednoczonych w jednej z wypowiedzi pojawia się metaforyczne użycie biblijnych nazw Sodoma $i$ Gomora w znaczeniu 'wielki rozgardiasz, zamieszanie, panika': Помню, 11 сентября 2001 года я, как обычно, включил телевизор и вижу по всем каналам горящие башни, в которые врезались самолеты - паника, руины, пожар, словом, Содом и Гоморра.

Nacechowane aksjologicznie przenośnie z komponentem proprialnym moga naświetlać określone zjawisko w sposób pozytywny. W tym wypadku podstawą wartościowania są konotacje o zabarwieniu dodatnim - melioratywne. Przykładowo, Nowym Jorkiem [...] we wschodnim stylu („Polityka" 2013, 36) nazwana została Moskwa z uwagi na przemianę z miasta 
szarości i biedy w kolorową, bogatą i kosmopolityczną metropolię, podobną do Nowego Jorku. Z treści artykułu opatrzonego tytułem Nasz Leonardo da Vinci („wSieci” 2013, 37) wynika, że jego autor odkrył wiele podobieństw między Mikołajem Kopernikiem i Leonardem da Vinci - obaj byli typowymi ludźmi renesansu, wszechstronnie uzdolnionymi, wykształconymi. Interesowali się wieloma dziedzinami życia, bardzo często od siebie oddalonymi. Potrafili dokonać wszystkiego, na co im przyszła ochota. Napoleonem mody („Wprost” 2005, 3) okrzyknięto Christiana Diora za wprowadzenie nowatorskich, rewolucyjnych zmian w świecie mody. Pozytywną ocenę zjawisk, opartą na konotacji 'wymarzona kraina szczęścia, ziemia obiecana, raj, źródło dobrobytu', niosą wyrażenia metaforyczne z nazwą Eldorado w strukturze, nр. Эльдорадо оптовьх закупок сzу настоящее Эльдорадо [...] для застройщиков элитного жилья. W pierwszym wypadku za pomocą przenośni określone zostało azjatyckie państwo Chiny, które jest ostatnio wielkim eksporterem tanich towarów do krajów europejskich. Potwierdzenie tego faktu znajdujemy też w innych synonimicznych metaforach, wyekscerpowanych z analizowanego tekstu: Китай сейчас - это Клондайк товаров с низкими иенами, [...] Аляска шоппинга. Drugie wyrażenie z toponimem Eldorado zawiera komentarz w sprawie przyznania rosyjskiemu miastu Soczi organizacji XXII Zimowych Igrzysk Olimpijskich w 2014 roku i korzyści płynących z tej decyzji dla branży budowlanej. Polska prasa także dostarcza wielu przykładów nacechowanych dodatnio metafor, zawierających nazwę Eldorado, por.:

1. Partie polityczne w Polsce sa przedsiębiorstwami. Kiedy partia wciśnie narodowi swój produkt (czyli sama siebie), dostaje od nas kilkadziesiąt milionów złotych rocznie. Wejście partii do parlamentu staje się finansowym eldorado („Wprost” 2010, 31),

2. Jak twierdza przedstawiciele organizacji zrzeszajacych firmy turystyczne, Polska zaczyna sie jawić niczym eldorado dla Europejczyków i Amerykanów ( „Newsweek” 2009, 16),

3. Singapur [...] ma być prawdziwym eldorado dla ludzi nauki z całego świata oraz wizytówka możliwości Singapuru („Polityka” 2008, 50),

4. Rzadzace Azerbejdżanem elity chca, by naftowe eldorado prędko sie nie skończyło. Dzięki ropie wciaż niezbyt zamożna republika notuje rekordowe tempo wzrostu gospodarczego ( „Newsweek” 2008, 48),

5. Po wieloletnim eldorado, finansowanym z pieniędzy klientów, banki płaca za grzech pazerności. Kara w postaci topniejacych zysków będzie surowa („Newsweek” 2009, 19).

Pokazany tu mechanizm wartościowania za pomocą metafor jest ogólnie dostępnym środkiem poznania i oceny rzeczywistości. Pamiętać jednak 
należy, że poznanie przez pryzmat przenośni nie jest obiektywne, lecz ukierunkowane już na etapie subiektywnego doboru metafor przez nadawców komunikatów prasowych, przesądzające o sposobie oglądu prezentowanych zjawisk. Ta właściwość metafor jest szczególnie przydatna w różnych gatunkach tekstów publicystycznych, nastawionych m.in. na realizację funkcji perswazyjnej, polegającej na komentowaniu i ocenianiu rzeczywistości [Kozieł 2002, 119, Bauer 2000, 150] w taki sposób, aby przekonać odbiorców do określonego stanowiska czy też skłonić do pewnych zachowań.

Komponentem metafory wartościującej może być nazwa własna i kojarzone z nią treści konotacyjne, pełniące w wypowiedzi przenośnej rolę nośników ocen ukierunkowanych negatywnie bądź pozytywnie. Metafory z udziałem jednostek proprialnych, zwłaszcza powiązanych z konotacjami powszechnie znanymi, zakorzenionymi w tradycji, a więc wyróżniającymi się daleko idącą stereotypizacją, są łatwe do rozszyfrowania i, co za tym idzie, przekazują niezwykle czytelny obraz rzeczywistości, często, jak starałam się wykazać, ujmowany aksjologicznie.

\section{Literatura}

Apresjan J. D., 2000, Semantyka leksykalna. Synonimiczne środki języka, przeł. Z. Kozłowska, A. Markowski, Wrocław-Warszawa-Kraków.

Bartmiński J., 2003, Miejsce wartości w językowym obrazie świata, [w:] Język w kręgu wartości. Studia semantyczne, red. J. Bartmiński, Lublin, s. 59-86.

Bauer Z., 2000, Gatunki dziennikarskie, [w:] Dziennikarstwo i świat mediów, red. Z. Bauer, E. Chudziński, Kraków, s. 150-158.

Dobrzyńska T., 1984, Metafora. Poetyka. Zarys Encyklopedyczny, Wrocław.

Encyklopedia językoznawstwa ogólnego, 2003, red. K. Polański, Wrocław-Warszawa-Kraków.

Gajda J., 1997, Wartości w życiu człowieka. Prawda - mitość - samotność, Lublin.

Kamiński S., 1986, Jak uporzadkować rozmaite koncepcje wartości?, [w:] O wartościowaniu w badaniach literackich, red. S. Sawicki, W. Panas, Lublin, s. $14-21$.

Kozieł A., 2002, Gatunki dziennikarskie - rodowód, cechy, funkcje, [w:] O warsztacie dziennikarskim, red. J. Adamowski, Warszawa, s. 115-120.

Krzeszowski T., 1999, Aksjologiczne aspekty semantyki językowej, Torun.

Kurczab H., 2012, Z problemów wartości i wartościowania (wybrane zagadnienia), „Zeszyty Naukowe Uniwersytetu Rzeszowskiego. Seria Filologiczna” z. 72, s. $7-37$.

Laskowska E., 1992, Wartościowanie w jezyku potocznym, Bydgoszcz. 
Ożóg K., 2001, Polszczyzna przełomu XX i XXI wieku. Wybrane zagadnienia, Rzeszów.

Puzynina J., 1992, Język wartości, Warszawa.

Puzynina J., 1997, Stowo - wartość - kultura, Lublin.

Rutkowski M., 2007, Nazwy własne w strukturze metafory i metonimii. Proces deonimizacji, Olsztyn.

Stróżewski W., 1992, W kręgu wartości, Kraków.

Tokarski R., 1984, Struktura pola znaczeniowego (studium językoznawcze), Warszawa.

\author{
METAPHORS WITH PROPER NAMES IN THEIR STRUCTURES \\ AS AN EXPONENT VALUATION \\ (BASED ON POLISH AND RUSSIAN JOURNALISTIC WRITING)
}

\title{
S U M M A R Y
}

One of the aspects of the secondary use of proper names, their metaphoric function, is under consideration in the paper.

Proper names as metaphors, through a variety of connotative content, relatively often provide some type of evaluation of reality. These evaluations can be negative, for example, nowe wcielenie doktora Mengele, żydowski Stalin, cepбcкas Голгофа or positive, for example, Napoleon mody, nasz Leonardo da Vinci, Эльдорадо оптовых закупок.

The evaluation process with a metaphor is a generally available way of getting to know and assessing reality. This universal means of communication is frequently applied by authors of journalistic texts. 